\title{
Holden Caulfield: An Outcast of His Society-An Analysis on Caulfield's Spiritual Dilemma Based on American Character
}

\author{
HE Wei \\ Sichuan University of Arts and Science, Dazhou, China
}

\begin{abstract}
Holden Caulfield, hero of the novel The Catcher in the Rye by J. D. Salinger, occupied the center of many critics after its publication. Holden, as a sixteen-year-old teenager, is full of confusions on the threshold of adult world, and really needs his parents and the society's guidance but nowhere can he get it; therefore, he gets lost on the threshold of adult world. This thesis tries to analyze Holden Caulfield's spiritual dilemma based on the theory of American Character developed by David Riesman. America turned into an "other-directed" society after the World War II, which highly advocated personal achievements. Everyone at that time was deeply influenced by that social character. Holden failed to acquire the social character in "other-directed" society in his childhood; consequently, he became the outcast of his society, and stuck in the spiritual dilemma with no way to get out.
\end{abstract}

Keywords: The Cather in the Rye, other-directed society, Gaze, spiritual dilemma

\section{Introduction}

Holden Caulfield, hero of the novel The Catcher in the Rye by J. D. Salinger, became a favor of many readers just after its publication, and occupied the center of many critics for many years. As a 16-year-old teenager, he was stuck into a spiritual dilemma. On the one hand, he cursed phonies around him; one the other hand, he acknowledged that he was the most terrible liar others ever saw in their lives; he cherished innocence, while deeply attracted by adult world (bar, prostitute). His spiritual dilemma can be traced back to his childhood, when he should have molded his character conforming to his social character.

\section{Change on Social Character: From Inner-Directed to Other-Directed}

David Riesman, Nathan Glazer, and Revel Denny (1966) once wrote in their book The Lonely Crowd-A Study of the Changing American Character,

The forming process of our character is the more or less permanent socially or historically conditioned organization of an individual's drives and satisfactions - the kind of "Set" with which he approaches the world and people... The notion of social character permits us to speak of the character of classes, groups, regions and nations. (p. 4)

Then how one forms his own character is strongly influenced by the character his society. As Erich Fromm (1948) suggests: "In order that any society may function well, its members must acquire the kind of character which makes them want to act in the way they have to act as members of the society or of a special class with it" (Kluckhohn \& Murray, 1994, p. 380). Meanwhile, society keeps on developing over time, so with the social character. David Riesman (1966) analyzed the change of American character, namely

HE Wei, lecturer, M.A., School of Foreign Languages, Sichuan University of Arts and Science. 
"traditional-directed, inner-directed and other-directed" (p. 8).

Back to Middle Ages and even before, society kept stable for a long time. People lived in a big family, and they had been educated to follow the traditional rules since their childhood. This kind of tradition-directed people would hardly think of themselves as individuals. They used this perspective to approach the society. Later, inner-directed value replaced traditional-directed one. People used a new way to look at themselves and the world. In their eyes, the world was full of all kinds of possibilities and many novel situations which need their initiatives. Free spirit was implanted early by the elders. Robinson Crusoe, a typical inner-directed example, was free to pursue the life he wanted. So with the early settler in new land, they are brave enough to follow their heart, suffering a lot to try their fortune in foreign land. As societies became more technologically developed, Riesman argued, parents give up some of their authority to other institutions such as schools, the mass media, and peer groups... Riesman called this new society "other-directed". Riesman maintained that other-directed societies lead to stability and tolerance, but also foster conformity and loss of individuality. The children in this kind of society were educated in some institutions. People were so aware of the smallness of themselves in this big society, and they tried their best to catch up with the society according to many outer influences - mass media, movies, radio, comics, popular culture, and peer group with the hope of winning the approval of the society. Riesman illustrated the point by telling the story of a boy who, when asked if he would like to fly, replied, "I would like to be able to fly if everyone else did" (Salinger, 2008, p. 60).

Actually, Holden Caulfield is living in "other-directed" society. Though he is educated in Pencey Prep, he is deeply skeptical about this whole character molding process carried by his school. He is puzzled with the ideology he learns, like he does not understand why Dr. Thurmer and Old Spencer keeps on talking that life is a game and they need to play according to the rules. Holden is obsessed with many questions about the society before getting into his adulthood.

\section{Character Molding Period: Absence of Emotional Support}

Living in an "other-directed" society, Holden finds himself alien from the prevailing social value. He was expelled from Pencey Prep, becoming a total loser in other's eyes. He feels homeless physically and emotionally which forces him to run away, wandering in New York City for three days. Around him, there are no nurturing parents to embrace him with comforting arms, and no reasonable adults to hear his needs and provide the emotional care for him. Then why he did not form the perspective as others? According to David Riesman, the years of childhood are of great importance in molding character. Then let's go to Caulfield's childhood first.

Born in an upper-class family, Holden enjoys the affluent material life provided by his parents, while how about his inner world? Holden's father, a very successful lawyer in society, is always busy with his job; it is seldom to see him take care of his son except one talks about Holden's terrible condition with his former teacher Antolini, "you are aware, of course, that he's terribly concern about you" (Salinger, 2008, p. 416), but his concern comes after getting the letter about Holden's poor behavior at school. In the whole book, his father never tries to get to know Holden, and only cares whether Holden can go to the famous university and become as successful as him. So after his younger sister Phoebe knows the news of his being kicked out of Pencey, this little girl cannot help repeating one sentence, "Daddy'll kill you!" (Salinger, 2008, p. 400). In addition, Holden's father himself is emotionally crippled, who is described as "quite touchy" about "anything pretty personal about him" (Salinger, 2008, p. 217). He actually is not a person who can deal with emotional problems 
even about himself; consequently, when he cannot get Holden to have a psychoanalyst for Allies death, the only way he takes is to threaten Holden by sending Holden to a military school—one version of juvenile delinquency for attitude adjustment in the 1950s. Feeling totally disappointed with his father, Holden is disdainful of the value system advocated by his father, and is suspicious of the society represented by him.

Holden's mother should give more emotional care to Holden; unfortunately, what she does is just on the contrary: She is presented as a distant figure in his son's life and so deeply obsessed with the grief of losing Allie, her excellent son. As Joyce Rowe (1991) observes, "too nervous and anxious about herself to do more than pay perfunctory attention to her children's need" (p. 89). She is alienated from her other children, and indulged in her own world. Though Holden hides himself into the closet on hearing the coming of her parents, he is badly in need of her care, "Mother Darling, give me your hand. Why won't you give me your hand?" (Salinger, 2008, p. 238). Concerning the absence of parental role model in the book, Gerald Rosen (1990) had once said,

The absence of Holden's parents (along with the absence of real religious guidance in misses being able to turn to his parents in his time of trouble... so Holden cannot get advice on how to leave the world of childhood from the adults around him. (p. 162)

Then how about his life at school, when standing on top of Thompson Hill in solitary after being ostracized for losing the fencing team's gear in the city, Holden looks down upon his schoolmates gathered for the traditional football rivalry with Saxon Hall: "you could hear them all yelling, deep and terrific on the Pencey side, because practically the whole school expects me was there" (Salinger, 2008, p. 218). In addition, how about his history teacher-Mr. Spencer? To his disappointment, this visit turns out to be a lecture which he feels so disgusting, and his attempt of communication ends up as a total failure. What is more, his roommate Standlater is a total sex bastard who is just obsessed with having sex with different girls; and all Standlater cares is to make himself look decent and gorgeous, and he does not care to help Holden to endure that hard period but ask him to do things for his date. No one Holden can talk with, and no one can understand him, the only company is loneliness, especial on that cold Sunday, "Boy, did I fell rotten. I felt so dame lonesome" (Salinger, 2008, p. 267).

It is obvious that there is no one who ever provides the emotional support to Holden and no one really cares to know how to help Holden out, then he decides to run away to face a cold night without sure shelter while the others sleep tight in their dormitory.

\section{Outcast of the Society: Under the Gaze of the Society}

The concept of the Gaze describes how the viewer gazes upon (views) the people presented and represented, which becomes a popular term in analyzing social power relations. Living in other-directed society, Holden is definitely under the gaze of his society.

In other-directed society, one got to know his image in others' eyes; in another way, one was under the gaze of people around him familiar or unfamiliar. Meanwhile, he should adjust himself to look well in others' eyes. After the industrial revolution, personal achievement was highly advocated. Therefore, everyone hoped to be successful in other' eyes. Meanwhile, he felt powerless under the huge machine of society, just like the chess on the board. 
The economy boom of the 20th century of America made people enjoy a more convenient life which stirred their desire for money and status. Consequently, wealth and social status became the only criterion to evaluate one's success. Children were cultivated to be a successful person as society required, like Holden's father, brother, and classmates. However, Holden was the exception.

This novel begins with Holden's escape from Pencey. Holden has flunked four subjects, which distinguishes him from the splendid, clear-thinking young men. Pencey is dedicated to cultivate. In Holden's mind, education system just turns people into "phony". He never pays attention to the score and alike. His life at Pencey ends with failure; therefore, he becomes a complete loser in others' eyes. Consequently, Holden feels there is no place for him anymore, and then he decides to escape. With all his savings, Holden leaves Pencey to enjoy few days' independence in New York City. The desire to avoid being looked as a loser makes him wandering in New York alone. His poor performance at school makes him so afraid of seeing his parents; therefore, he hides him into a closet on hearing of their back. While his action of "accidentally" giving the cab driver the address of his parent's apartment betrays his desire to be back to his boyhood home. Though the home is the same one, his return will not be welcome but arouse their anger and disappointment. Then he decides to hit the town and tries to construct his own home in the hotel, which ended with another failure. He only felt lonely at that empty home. He really does not know how to adopt himself to the adult world to play game. Meeting Horwitz, a friendly talker, Holden invites him to have a drinking with, which ends with Horwitz's reply as "Why ain’tcha home in bed?" (Salinger, 2008, p. 305). Later in his wandering, the little drunk Holden confronts a piano player in Wicker Bar who urges his to "Go home, Mac, like a good guy, Go home and hit the sack" (Salinger, 2008, p. 380). The drunken Holden reveals a truth he will not want to face, "No home to go. No kidding" (Salinger, 2008, p.380), just after leaving the Bar, he is crying and "feeling so damn depressed and lonesome" (Salinger, 2008, p. 402).

\section{Conclusion}

Holden unconsciously knows his loser image in others' eyes. Unfortunately, he is unable to find any area-school, family, friends, city, religion, movie, or theater - in which he can get just a touch of comfort. The loneliness follows him whenever he goes, and he feels like an outsider, which is perfectly represented by his miserable odyssey from a privileged prep school to a nursing home, trying to look for a refuge along the way at nightclubs, hotels, theaters, museums, skating rinks, and his family apartment that turns out no home at all.

\section{References}

Individual and social origins of neurosis. (1994). American Socialogical Review, IX, 380. (Reprinted in C. Kluckhohn and H. Murray (Eds.). (1948). Personality in nature, society and culture. New York: Alfred A. Knopf).

Riesman, D., Glazer, N., \& Denny, R. (1966). The lonely crowd-A study of the changing American character (Abridged edition with a new foreword). America: Yale University Press.

Rosen, G. (1990). A retrospective look at The Catcher in the Rye. America Quarterly, 5(Winter 1977), 547-562. In J. Salzberg (Ed.), Critical essays on Salinger's The Catcher in the Rye. Boston: G.K. Hall.

Rowe, J. (1991). Holden Caulfield and American protest. In J. Salzmann (Ed.), New essays on The Catcher in the Rye. Cambridge: Cambridge University Press.

Salinger, J. D. (2008). The catcher in the rye. Nanjing: Yiling Press. 